\title{
DEVELOPING HALAL TRAVEL AND HALAL TOURISM TO PROMOTE ECONOMIC GROWTH: A CONFIRMATORY ANALYSIS
}

\author{
Abrista Devi ${ }^{1}$ and Irman Firmansyah ${ }^{2}$ \\ ${ }^{1}$ Research Consultant at SMART Consulting, Indonesia, abristasmart@gmail.com \\ ${ }^{2}$ Lecture at Accounting Department, Economics Faculty, Siliwangi University, Indonesia, \\ irmanfirmansyah@unsil.ac.id
}

\begin{abstract}
The purpose of this paper is to identify the factors of various backgrounds in the literature having to do with halal purchase intention of Muslim travellers on halal travel and tourism sector. It also aims to investigate which antecedents, among all, that have the dominant determinants toward the development of halal travel and tourism purchase intention. A total of 255 respondents originating from several major cities of West Java were involved in random sampling technique to measure their personal perception on the determinant factors of halal purchase intention. Data were collected through structured questionnaire with a five-point Likert scale. The questionnaire has been divided into two main parts, the first part identifies the respondent identity, while the second part provide 6 main sub-part statements on halal awareness, personal societal perception, religious belief, halal marketing, halal travel \& tourism, and infrastructure. Confirmatory Factor Analysis (CFA) will be used to acquire the most critical to the least critical indicators in explaining purchase intention on halal travel and tourism industry sector. The paper concludes that most customers rely on halal marketing, making it the dominant determinant factor. Meanwhile, the second dominant determinant is halal travel and tourism. Then, the third determinant is halal awareness. Religious beliefs and personal societal perceptions are the last two priorities. This paper offers a detailed insight into various behaviors of customer's purchase intention on halal travel and tourism sector as well as delivers a new model of purchase intention through detailed latent-variables. Finally, the relevant stakeholders, in particular government, should enhance the halal marketing on travel and tourism through various programs and activities, such as massive promotion, socialization, and literacy.
\end{abstract}

Keywords: Halal awareness, Halal marketing, Personal Societal perception, Religious belief, Halal travel and tourism.

JEL Classification: M31; M21; L88; J17.

Article history:

Received : October 27, 2018

Revised : February 18, 2019

Accepted : February 26, 2018

Available Online : 15 Maret 2019

https://doi.org/10.21098/jimf.v5i1.1054 


\section{INTRODUCTION}

Halal travel and tourism is currently the most promising sector in many countries, including Indonesia. It is well known that, Indonesia is a popular country, where we can find a lot of travel alternatives in each regional destination. Halal is identified as anything that are permissible or lawful under sharia or Islamic value (Awan, Siddiquei, \& Haider, 2015; Zakaria \& Abdul-Talib, 2010). In supporting this assertion, another definition mentions that halal as the way of Islam to regulate the Muslim way of life that involves Muslim behavior, speech, dress, conduct, manner and dietary (Al-Jallad, 2008). Pahim, Jemali, \& Mohammad (2012) generally address the definition of halal industry, which is not only related to food sector, but also non-food sector, such as pharmaceutical, cosmetics, logistics, banking and tourism. Even though previous studies mostly discuss halal food, halal also involves the entire Muslim activities, such as presenting the concept of religious travel and tourism, which represents other kind of halal sector (Jaelani, 2017). The tourism based on Islamic religion is defined as having a trip which is followed by religious activities motivation as well as derived from Islamic motivation (Din, 1989; Jaelani, 2017).

In supporting the term of halal travel and tourism, Law of Tourism No.10/2009, Chapter III provides six principles. To begin with, the principle is highly related to upholding the religious norms and cultural values become the embodiment of the concept of life in the balance of the relationship between man and God Almighty, the relationship between man and his fellow man, and the relationship between humans and the environment. The next principle is to uphold human rights, cultural diversity, and local knowledge. Furthermore, the principle benefits for the people's welfare, justice, equality, and proportionality, and preserving the nature and environment, as well as empowering local communities. Moreover, the principle ensures the integration among sectors, regions, center and area within the framework of regional autonomy and integration, as well as complying with the code of conduct world tourism and international agreements in the field of tourism. Finally, the priority is to strengthen the integrity of the unitary Republic of Indonesia.

The development of halal travel and tourism in Indonesia also highlighted by (Jaelani, 2017) that halal travel and tourism became one of the national industries with economic potential for Indonesia. Data retrieved from Bappenas in 2016 confirmed that Indonesia experienced an increase of world tourism up to $2.9 \%$ in 2015 and 12 million of tourist arrivals in 2016. Indonesia placed the fourth in regional tourism ranks after Thailand, Malaysia and Singapore. Meanwhile, as far as nationality is concerned, Singapore, Malaysia, and China are the largest contributors toward foreign tourists, whereas tourists from Australia, United Kingdom, and United States are accounted for as those coming outside Asia. Local data provided useful information on the rank of Indonesia tourism index in 2016, where Denpasar, Bali took the highest rank, followed by Surabaya (East Java) as the second, and Batam (Riau) the third. Sleman (Yogyakarta) and Semarang (Central Java) placed fourth and fifth in the ranking, whereas Bandung (West Java), Banyuwangi (East Java), Bogor (West Java), and Bantul (East Java) were in the last-four rank (www.liputan6.com). 
Although there are a few empirical studies investigating the halal travel and tourism sector, nearly 80 percent of previous studies discussed the determinant factors of halal supply chain in many countries and only 20 percent examined halal purchase intention behavior, specifically in halal travel and tourism in Indonesia. For instance, (Jaelani, 2017) empirically analyzed the need of developing halal travel and tourism as Indonesia's strength for the future. Halal travel and tourism has a significant contribution to the economic growth of Indonesia, considering Indonesia has a lot of natural resources that can be developed to attract more visitors (Samori, Salleh, \& Khalid, 2016). Moreover, Awan et al. (2015) examined the relationship of factors influencing customer's halal purchase intention in Pakistan. The findings highlighted halal marketing, personal and societal perception, and halal certification significantly affecting Muslim purchase intention of halal food. Previous research (Tieman, Vorst, \& Ghazali, 2012) supported the view that product characteristics and market requirements significantly determine the supply chain vulnerability to halal contamination. In addition, Ab-Talib et al (2015) considered some critical success factors of halal supply chain that constitute human resource, government support, well built collaborative relationship, transportation planning, information technology, halal certification, and lastly, halal traceability.

However, it is fair enough to state that there is still a lack of studies about halal travel and tourism. As such, none of the studies discussed the determinant factors of Muslim purchase intention on halal travel and tourism or was empirically based in Indonesia. On the other hand, Indonesia is popular with travel and tourism. Besides, Indonesia is a country with the largest Muslim population in the world. Therefore, it is urgently required to explore to what extent the Muslim population in Indonesia is willing to purchase halal travel and tourism services. Previous studies also examine different variables toward halal sector. Therefore, this study attempts to examine some relevant factors by employing $2^{\text {nd }}$ CFA approach, which is Halal Awareness, Personal Societal Perception, Religious Belief, Halal Travel and Tourism, and Infrastructure toward Muslim purchase intention on halal travel and tourism in West Java, Indonesia.

Moreover, the research sets out to achieve the determinant factors of Muslim intention on spending to halal travel and tourism sector in West Java, Indonesia. This study attempts to capture the appropriate strategies to enhance halal travel and tourism sector in Indonesia. This study also intends to help government in order to create worth policy and regulations on halal travel and tourism. Other relevant stakeholders, such as travel and tourism businessman, Muslim society, and academia also become significant object of this study.

The remainder of the discussion is divided into four sections: the second section reviews the literature and previous studies on halal intention purchase, the third discusses the methodology and data, and the last section comprises conclusion and implication of the study.

\section{LITERATURE REVIEW}

\subsection{Measuring Purchase Intention on Halal Travel and Tourism}

Intention can be defined as the willingness of people to do something based on their perception. Intention model was developed (McStay, 2008) and firstly introduced 
under the Theory of Planned Behavior (Ajzen, 1991). McStay argues that this theory has the capability to describe people behavior and their intention to the activity, in terms of purchasing behavior (McStay, 2008). Three main indicators can explain intention, which is attitude toward the behavior, subjective norms, and perceived behavioral control. Theory of Planned Behavior argues that most of human behavior comes from individual intention to show specific behavior and their ability to decide between the choices and/or to create the decision to do something on their willingness. Interestingly, Liu et al. (2018) introduced the term of travel intention in representing the purchase intention on travel and tourism product, which means as public attitude towards choosing travel activities.

A plethora of academic evidence discusses the determinant factors of purchase intention on halal travel and tourism. Therefore, this current research considers six aspects that are considered to describe Muslim purchase intention on halal travel and tourism, all constituting halal awareness, religious belief, personal societal perception, halal marketing, halal travel and tourism, and infrastructure.

Halal awareness can be defined as the consumer knowledge on halal principles that have an impact toward their intention to purchase halal products (Awan et al., 2015). Halal awareness is all about the Muslim awareness on halal product consumption. The importance of being aware of the knowledge about culture will open the opportunity of Indonesia to becoming "Indonesia the halal wonders" in halal travel and tourism (Winarti, 2017). The indicators of halal awareness involve searching detail information about the place that will be visited by Muslim customers, ensuring the availability of halal product and services, for instance, the availability of halal food, mushola/masjid, clean toilet and sanitary, and the availability of water for wudhu, as well as the government responsibilities to ensure and provide halal product and services at the recreational place. The issue of government support is important to ensure the availability of halal product and services in terms of halal travel and tourism in order to having the competition in the international market (Gunasekaran \& Ngai, 2003). At the same time, addressing the issue of halal market is a lucrative business for a billion of Muslim customers supported by the government. The partnership helps and promotes halal industry, for instance, by setting up a halal certification authority, especially in the Halal Travel and Tourism sector by providing incentives for halal business, funding research on halal-related studies through universities and research institutes, as well as organizing halal training for industry business owner (Ab-Talib et al., 2015).

Halal marketing plays a significant role to satisfy Muslim consumers's demand to purchase halal product (Awan et al., 2015). It is widely believed that Muslim consumers are slightly different with conventional consumers in that they tend to seek the product and services not only of a good quality, but also with sharia compliance. Therefore, halal marketing is urgently needed to establish and strenghten Muslim awareness and literacy on halal product and services.

Personal Societal Perception is involved in the following indicators: (1) Indonesian communities place the priority toward halal travel and tourism in their localities, (2) Indonesian communities have a lot of choices toward halal travel and tourism, (3) halal travel and tourism is easy to find and access, (4) positive perception of Muslim toward halal travel and tourism potential in Indonesia, and (5) the willingness of Muslim consumers to obtain detail information toward halal 
travel and tourism in Indonesia. Awan et al. (2015) argues that spiritual values and religiosity set behavior standards influence the consumer's choices on the activity attributes. In supporting this assertion, Ahmed (2008) argues that spiritual values can affect the lifestyle of customers as well as their actions in doing something. Meanwhile, Essoo \& Dibb (2004) confirm that customer perception and their trust on religion will become an important part of consumption actions. Religion plays an important role in someone's decision to spend their time (Jaelani, 2017). Religious beliefs provide information regarding the searching of halal travel and tourism based on the religious reasoning, and most is accepted by the social and family, the obligation of Islam religion, avoidance of haram/makruh transaction, and avoidance of the doubt in halal.

Ab-Talib et al. (2015) indicate the need of government support to improve halal and tourism of a country by providing a strong platform for halal business to prosper and conducting research and training in collaboration with higher education. Halal control is the most important factor to ensure that industry can provide halal travel and tourism to the customers (Tieman et al., 2012) and control activities involving the design and platform that can used both in short term and long term policies to improve halal travel and tourism in a country. Halal travel and tourism involve the following indicators: (1) the regulation on halal travel and tourism, (2) subsidies and incentives from the government to improve halal travel and tourism sector, (3) short term and long term road maps on halal travel and tourism, (4) priority activities of the regional/province government, and (5) partnerships among government, halal travel and tourism stakeholders, and travel and tourism business owners.

Halal infrastructure remains as one of the most important determinant factors in halal travel and tourism. Jaelani (2017) offers important indicators of halal travel and tourism infrastructure, such as facilities of worship, the availability of halal culinary area, a guide with full understanding and mastery in tourism and halal information, and the entertainment that is provided to the customer in order to increase their spirituality. Halal infrastructure involves the following indicators: halal food, the availability of worship platform, the availability of comfort and clean water in the toilet, the availability of facility and services during Ramadhan, the absence of non halal activities (forbidden activities), private leisure activities, high attitude of human resources (for instance, wearing Hijab), safety and comfort for Muslim travelers, and easy access for transportation.

With that in mind, the proposed research questions are stipulated. First, what are the factors contributing to Muslim's consumer purchase intention on halal travel and tourism in West Java, Indonesia? Second, what are the individual elements that create this purchase intention based on the level of their priority? Third, what are contributions of different factors of halal travel and tourism toward overall purchase intention?

\subsection{Previous Studies on halal Travel and Tourism}

Awan et a;. (2015) investigated the various antecendents which is affecting halal purchase intention of food sector in Pakistan over 300 respondents. The research indicated that most Pakistani's consumers rely on halal marketing, personal 
societal perception, and halal cetification when making a purchase decision. Promotion and celebrity endoresements became two most important indicators of halal marketing. On the other hand, religious belief was the least importance for Pakistani's consumer to make a purchase decision on halal food product. The study also highlighted that the customers have high willingness in spending more money and efforts to purchase halal food.

Liu contend that there are several aspects which will positively affect a Muslim tourist's travel intention that constitutes a Muslim friendly tourism, tourist attitude, and destination image (Liu et al., 2018). In addition, some public infrastructure or places are also required to satisfy Mulism tourists needs on halal travel and tourism, for instance, the availability of prayer spaces (mosque), convenient toilet facitilites, halal restaurants and hotels, and the availability of halal food and beverage. The increasing halal travel and tourism infrastructure and facilities will greatly contribute to the increasing of economic sector. Tichaawa \& Mhlanga (2018) support the view that prayer facilities significantly affect the Mulism tourist experience. Similarly, halal food will create repurchase activities of Muslim costumers. As a result, it is considerably important for the travel and tourims business owner to focus on the unique attribute o fdelivery to be considered to have an impact on Muslim purchase intention.

Establishing a halal supply chain model iss considerably important instrument in order to satisfy the halal integrity from the point of consumer purchase (Ab-Talib et al., 2015; Tieman et al., 2012). Moreover, Ab-Talib et al. (2015) consider some critical success factors of halal supply chain, which constitutes human resources, the government support, well built collaborative relationships, transportation planning, information technology, halal certification, and halal traceability. Suligoj and Marusko (2017) identified the halal certification as determinant factors $\mathrm{n}$ Muslim purchase intention. Further, businessmen will have an interest to adopt halal certification on their product and services only if the relevant government is able to provide a clear and simple procedure for obtaining the halal certification. Some factors can be considered to improve the businessmen's perception and understanding on the complexity to obtain halal certification. For instance, clear halal standards, education and training program, and publicly available materials. Last, it also has been noticed that in order to fully support the growth of halal industry, the government needs to establish a master plan or blue print on halal industry (Johannes, 2009).

From those all existing studies, it can be concluded that still there is a lack of studies on halal travel and tourism, particularly in measuring Muslim purchase intention on halal travel and tourism product. However, it is generally claimed that there are several factors that significantly affect Muslim purchase intention on this sector, such as halal marketing, personal societal perception, halal certification, transportation planning, information technology, regulation and policy, religious beliefs, and others. This current study attempts to put some factors altogether in a confirmatory model to discover the determinant factors of Muslim purchase intention on halal travel and tourism in West Java, Indonesia. 


\section{METHODOLOGY}

\subsection{Data}

Quantitative methods were implemented in this study, including Confirmatory Factor Analysis $\left(1^{\text {st }} \mathrm{CFA}\right)$ and Second Confirmatory Factor Analysis ( $\left.2^{\text {nd }} \mathrm{CFA}\right)$ to identify the determinants of Muslim's purchase intention (PE) on halal travel and tourism. According to Hair et al. (2014) and Baumgartner \& Homburg (1996), the minimum sample of SEM (Structural Equation Modeling) requires at least no lesser than 5 times the number of indicators. The data were collected from $255 \mathrm{Muslim}$ in a questionnaire survey in West Java, Indonesia. Random sampling technique was used to obtain the selected respondents.

The indicators used in this study constitute six aspects: (1) halal awareness, including searching detail information, ensuring halal product and service facility, and responsibility for the availability of halal product and services (Awan et al., 2015; Winarti, 2017); (2) personal societal perceptions, including giving priority toward halal tourism, various halal destination, accessibility, positive perception on halal travel and tourism, and willingness to search information on halal (Awan et al., 2015); (3) religious beliefs, including religious reasons, high acceptability, religion command, avoidance of halal transactions, and avoidance of doubtful transactions (Ahmed, 2008; Essoo \& Dibb, 2004; Jaelani, 2017); (4) halal marketing, including celebrity endorses, halal certificate, affordable price, promotion, and unique religious experience (Awan et al., 2015; Tieman et al., 2012); (5) halal travel and tourism regulation, including halal travel and tourism law, subsidy and intensive, long term road map, priority activity, and cooperation among stakeholders (Ab-Talib et al., 2015; Gunasekaran \& Ngai, 2003; Tieman et al., 2012); and (6) infrastructure, including halal food, places of worship availability, clean sanitation, service and facility during Ramadhan, absence of non halal activity, private recreation facility, ethical employees, safety and comfortable, and accessible transportation (Jaelani, 2017).

\subsection{Confirmatory Factor Analysis \& $2^{\text {nd }}$ CFA}

Ascarya (2016) reviews the concept of 'Confirmatory Factor Analysis' (CFA) or 'Exploratory Factor Analysis' (EFA) to describe the measurement of variable indicators or measured variables reflecting their respective latent variables. The proposed variables are built up and selected based on underlying theories. CFA as a type of Structural Equation Modeling (SEM) that deals specifically with measurement models, i.e., the relationships between observed measures or indicators. Additionally, CFA has become one of the most commonly used statistical procedures in applied research (Brown, 2006). Therefore, in this study, CFA will be used to get the most critical to the least critical indicators in explaining purchase intention of the halal travel and industry sector.

This study attempts to develop factor analysis to become the second order factor analysis to overcome some latent variables that underlie the indicators in large numbers. Besides, the second order is aimed to discover some latent variables that are closely related to the concepts of the indicators. We assume that there are more general and abstract latent variables that might underlie or influence "level one" or "first order" latent variables. To clarify, latent variables that directly affect 
observed variables may be influenced by other latent variables that do not need to be directly related to the observed variables. In so doing, it is widely considered as 'higher order factor analysis'. The assertion aspect emphasizes that higher order factor analysis is more informative rather than first order (Anderson \& Gerbing, 1984).

Higher order factor analysis of this study comprises seven latent variables (first and second order of CFA). The path represents the first CFA model from halal awareness, personal societal perception, religious belief, halal marketing, and infrastructure towards their indicators. To begin with, the halal awareness factor (HA), with three indicators: searching detail information $\left(X_{11}\right)$, ensuring halal product and service facility $\left(X_{12}\right)$, and responsibility for the availability of halal product and services $\left(X_{13}\right)$. Next, personal societal perception (PSP) comprises five indicators: giving priority toward halal tourism $\left(X_{21}\right)$, various halal destinations $\left(X_{22}\right)$, easy to find $\left(X_{23}\right)$, positive perception on halal travel and tourism $\left(X_{24}\right)$, and willingness to search information on halal $\left(X_{25}\right)$. Third, religious belief (RB) comprises five indicators: religious reasons $\left(X_{31}\right),\left(X_{32}\right)$ high acceptability, religion command $\left(X_{33}\right)$, avoidance of halal transactions $\left(X_{34}\right)$, and avoidance of doubtful transactions $\left(X_{35}\right)$. In addition, halal marketing $(\mathrm{HM})$ consists of five indicators: celebrity endorsements $\left(X_{41}\right)$, halal certification $\left(X_{42}\right)$, affordable pricing $\left(X_{43}\right)$, promotion $\left(X_{44}\right)$, and unique religious experience $\left(X_{45}\right)$. Fifth, halal travel and tourism regulation (HT) comprises five indicators: halal travel and tourism law $\left(X_{51}\right)$, subsidy and intensive $\left(X_{52}\right)$, long term road map $\left(X_{53}\right)$, priority activity $\left(X_{54}\right)$, and cooperation among stakeholders $\left(X_{55}\right)$. Finally, infrastructure $(\mathrm{I})$ comprises nine indicators: halal food (X61), worship place availability $\left(X_{62}\right)$, clean sanitation $\left(X_{63}\right)$, service and facility during Ramadhan $\left(X_{64}\right)$, absence of non halal activity $\left(X_{65}\right)$, private recreation facility $\left(X_{66}\right)$, ethical employees $\left(X_{67}\right)$, safety and comfort $\left(X_{68}\right)$, and ease of transportation availability $\left(X_{69}\right)$. Meanwhile, the path represents the second CFA model from purchase intention (PI) towards its latent indicators. 
Figure 1. $2^{\text {nd }}$ CFA Model of Muslim's Purchase Intention on Halal Travel and Tourism

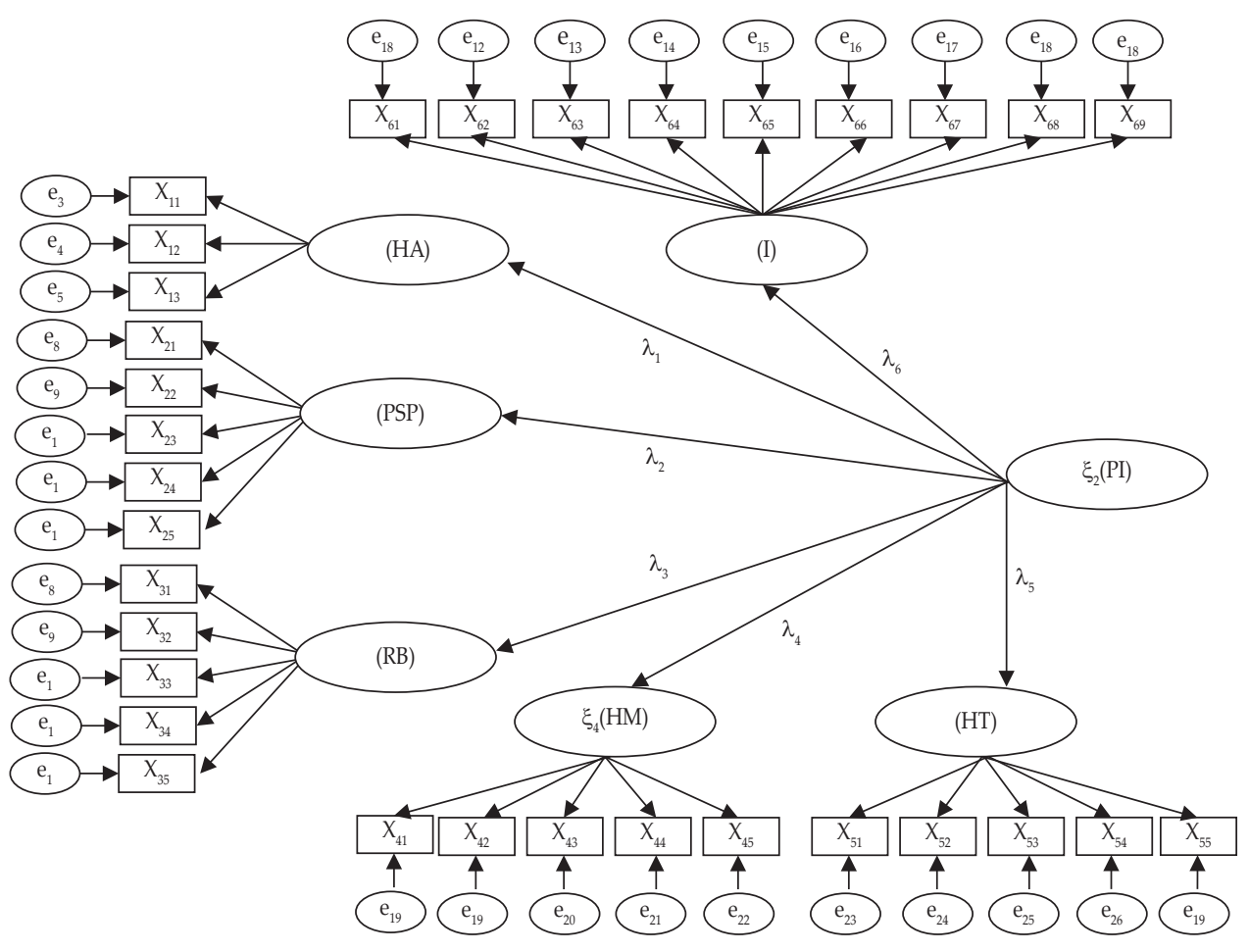

\section{RESULTS AND ANALYSIS}

\subsection{Respondents Description}

Data were collected using a questionnaire to 255 respondents who were members of urban and rural communities in West Java, Indonesia. The data were sufficient to meet the minimum requirement of the model. The description of the respondents is as follows:

\section{Gender}

Of all the respondents, 114 people or $44.71 \%$ were male respondents and 141 people or $55.29 \%$ female respondents. The following table shows the respondent recapitulation based on gender. 
Table 1.

Respondent's Gender

\begin{tabular}{lcc}
\hline Categories & Amount & Percentage \\
\hline Male & 114 & 44.71 \\
Female & 141 & 55.29 \\
Total & 255 & 100 \\
\hline
\end{tabular}

\section{Age}

The respondents were divided into five groups based on age. The first group $(0$ to 20 years) amounted to 47 people (18.43\%). The second group (21 to 30 years) comprising 117 people (45.88\%). The third group (31 to 40 years) consisting of 67 people $(26.27 \%)$. The fourth group (41 to 50 years) had 16 people $(6.27 \%)$. Finally, the group of respondents aged 51 and above made up $3.14 \%$ of the population ( 8 people). In so doing, the majority of respondents were people aged 21-30 years. Table 2 describes the classification of the respondents based on their age:

Table 2.

Age of Respondents

\begin{tabular}{lcc}
\hline Categories & Amount & Percentage \\
\hline$\leq 20$ years & 47 & 18.43 \\
$21-30$ years & 117 & 45.88 \\
$31-40$ years & 67 & 26.27 \\
$41-50$ years & 16 & 6.27 \\
$\geq 51$ years & 8 & 3.14 \\
Total & 255 & 100 \\
\hline
\end{tabular}

\section{Occupation}

The occupation criteria of the respondents varied from students, entrepreneurs, workers, both entrepreneurs and workers, non-entrepreneurs, and non-workers. The number of respondents who were students and/or college students was 90 people $(35.29 \%) .16$ people $(6.27 \%)$ were businesspeople. 109 people $(42.74 \%)$ were workers. 23 people $(9.01 \%)$ were both entrepreneurs and workers. 17 people $(6.67 \%)$ were non-entrepreneurs and non-workers. It could be concluded that the majority of respondents were workers. The following table shows the recapitulation of the respondents based on employment status. 
Table 3.

Occupation of Respondents

\begin{tabular}{lcc}
\hline Categories & Amount & Percentage \\
\hline Student & 90 & 35.29 \\
Businessman & 16 & 6.27 \\
Working & 109 & 42.74 \\
Business and working & 23 & 9.01 \\
Not business not working event & 17 & 6.67 \\
Total & 255 & 100 \\
\hline
\end{tabular}

\section{Education}

The study highlighted that there were no uneducated respondents. Only $0.39 \%$ respondents completed school at both elementary and middle/junior levels. 94 people $(36.86 \%)$ were senior high school graduates. 6 people $(2.35 \%)$ attended community colleges. $34.90 \%$ respondents or 89 people had a Bachelor degree. $21.17 \%$ respondents (54 people) had master's degrees. Last, $3.93 \%$ respondents (10 people) held doctoral degrees. Therefore, the majority of respondents were senior high school graduates. Table 4 describes the classification:

Table 4.

Education of Respondents

\begin{tabular}{lcc}
\hline Categories & Amount & Percentage \\
\hline Uneducated & 0 & 0 \\
Elementary & 1 & 0.39 \\
Middle/Junior & 1 & 0.39 \\
Senior & 94 & 36.86 \\
Diploma & 6 & 2.35 \\
Bachelor & 89 & 34.90 \\
Master & 54 & 21.17 \\
Doctoral & 10 & 3.93 \\
Total & 255 & 100 \\
\hline
\end{tabular}

\section{Marital Status}

As many as 138 people (54.12\% respondents) were unmarried. $43.53 \%$ respondents (111 people) were married. 5 people $(1.96 \%)$ were divorced and 1 person was a widow/er. Table 5 outlines the respondents' marital status:

Table 5.

Marital Status of Respondents

\begin{tabular}{lll}
\hline Categories & Amount & Percentage \\
\hline Unmarried & 138 & 54.12 \\
Married & 111 & 43.53 \\
Divorced & 5 & 1.96 \\
Widow / Widower left dead & 1 & 0.39 \\
Total & 255 & 100 \\
\hline
\end{tabular}




\section{Monthly Income}

The next category describes the respondents' income per month. The value of income is based on the amount of income received at the time before the questionnaire was distributed. The results show that the majority of respondents' income was no more than IDR 2,500,000 per month, which is 140 people or $54.90 \%$ of the population. Respondents who had income between IDR 2,500,000 to IDR 5,500,000 were 56 people, or over $21 \%$. The following table presents the respondents' recapitulation based on the amount of income per month.

Table 6.

Income per Month of Respondents

\begin{tabular}{lcc}
\hline Categories & Amount & Percentage \\
\hline$\leq$ IDR 2,500,000 & 140 & 54.90 \\
IDR 2,500,001 - IDR 5,500,000 & 56 & 21.96 \\
IDR 5,500,001 - IDR 7,500,000 & 29 & 11.37 \\
$>$ IDR 7,500,001 & 30 & 11.76 \\
Total & 255 & 100 \\
\hline
\end{tabular}

\section{Traveling Last Month}

The following data describes the amount of traveling made during the last month. The results showed that 155 people or $60.78 \%$ traveled 1-2 times in the last month, whereas 77 people did not travel at all. The number of respondents who traveled 3-5 times were 22. Those who traveled 6 times or more were 1 person. Thus, the majority of respondents traveled 1-2 times in the last month. For more details, the following table presents the number of trips made by respondents in the last month.

Table 7

Respondents' Last Month's Travel

\begin{tabular}{lcc}
\hline Categories & Amount & Percentage \\
\hline 0 trip & 77 & 30.20 \\
$1-2$ trips & 155 & 60.78 \\
$3-5$ trips & 22 & 8.63 \\
6 more trips & 1 & 0.39 \\
Total & 255 & 100 \\
\hline
\end{tabular}

\section{Have Heard "Halal Travel and Tourism"}

The last description is to find out if the respondents were familiar with the phrase halal travel. The following table shows that $61.17 \%$ respondents had previously heard about "halal travel" and the remaining 38.82\% had not heard of such a terminology. 
Table 8.

Respondents' Knowledge of the Term "Halal Travel and Tourism"

\begin{tabular}{lcc}
\hline Categories & Amount & Percentage \\
\hline Yes & 156 & 61.17 \\
No & 99 & 38.82 \\
Total & 255 & 100 \\
\hline
\end{tabular}

\subsection{Measurement Model of $1^{\text {st }}$ CFA}

The result of the measurement model of $1^{\text {st }}$ CFA will be discussed in this chapter thoroughly. Figure 2 describes halal awareness latent variables model with three indicators: HA1 (searching for detail information), HA2 (ensuring the availability of halal product), and HA3 (the government's responsibility on the availability of halal product). The measurement model of latent variables halal awareness (HA) satisfies two main conditions: P-Value > 0.050 (1) and RMSEA $\leq 0.08$ (0.000). All goodness of fit (GoF) measures are perfectly fit; therefore, we can conclude that the measurement model of halal awareness is a fit model. All indicators (HA1, HA2, and HA3) are identified significant in explaining halal awareness, as well as its validity and reliability (CR [Construct Reliability] $=0.74 \geq 0.70$ and VE [Variance Extracted $]=0.50 \geq 0.40$ ). The results indicate that ensuring the availability of halal product and the government's responsibility on the availability of halal product are the two highest indicators for the halal awareness of Muslim on spending to halal travel and tourism consumption. Searching for detail information takes the last priority of the model.

Figure 2. $1^{\text {st }}$ CFA Measurement Model of Halal Awareness

T-Value

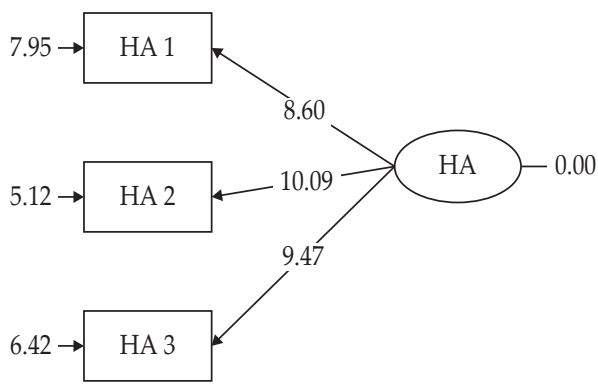

Standardized Solution

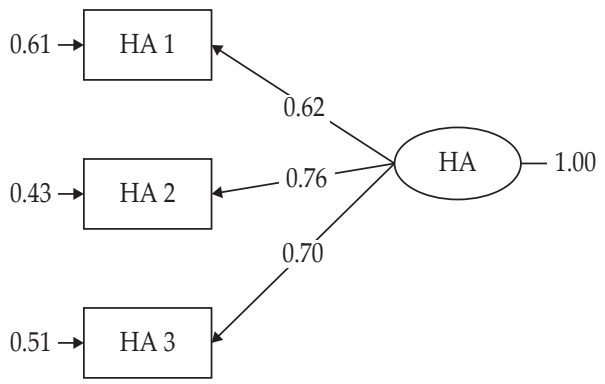

Chi-Square $=0.00 ; \mathrm{df}=0 ; \mathrm{P}$-Value $=1.00000 ;$ RMSEA $=0.000$

Figure 3 describes Personal Societal Perception latent variables model with five (5) indicators: PSP1 (giving priority on halal travel and tourism), PSP2 (providing massive choice), PSP3 (accessibility), PSP4 (positive perception), and PSP5 (willingness to search for information). The measurement model of latent variables Personal Societal Perception (PSP) satisfies several main conditions: P-Value $>0.050$ (0.17044), RMSEA $\leq 0.08$ (0.055), NFI $\geq 0.90$ (0.99), etc. All goodness 
of fit (GoF) measures is fit; therefore, we can conclude that the measurement model of Personal Societal Perception is a fit model. All indicators (PSP1, PSP2, PSP3, PSP4, and PSP5) are identified significant in explaining Personal Societal Perception, as well as its validity and reliability (CR [Construct Reliability] $=0.75 \geq$ 0.70 and VE [Variance Extracted] $=0.40 \geq 0.40$ ). The finding indicates that positive perception is the highest indicator to explaining the Personal Societal Perception of Muslim on spending to halal travel and tourism consumption, while giving priority on halal travel and tourism takes the last priority of the model.

Figure 3. $1^{\text {st }}$ CFA Measurement Model of Personal Societal Perception T-Value Standardized Solution
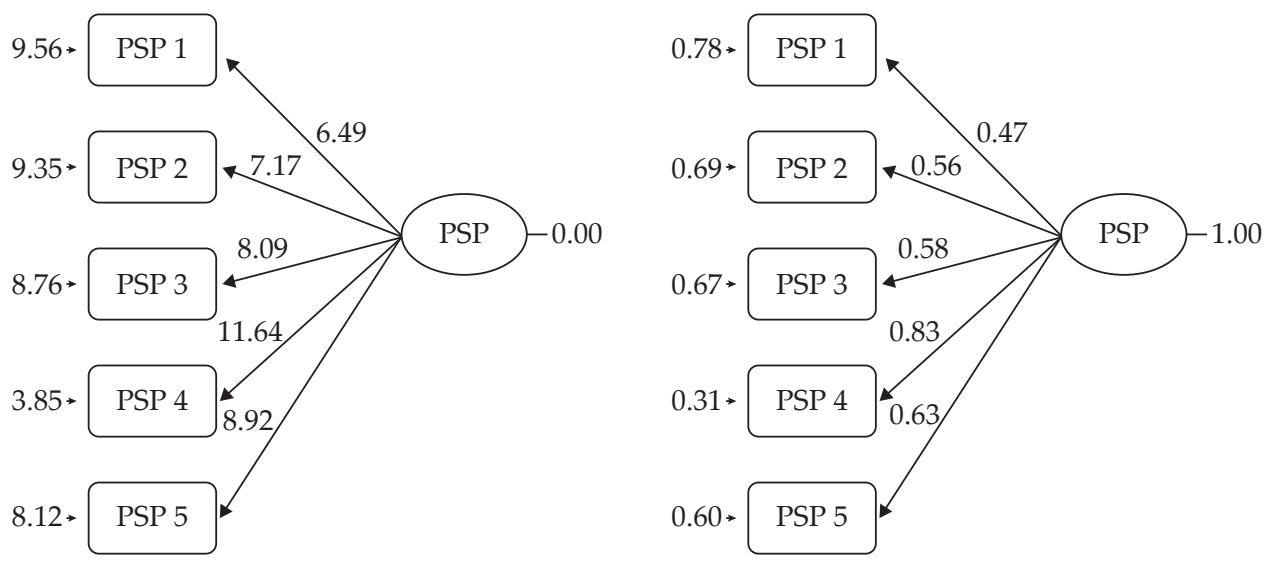

Chi-Square=5.02; $\mathrm{df}=3 ; \mathrm{P}$-Value=0.17044; RMSEA=0.055; NFI=0.99; NNFI=0.98; $\mathrm{CFI}=1.00 ; \mathrm{IFI}=1.00$; $\mathrm{RFI}=0.96 ; \mathrm{GFI}=0.99 ; \mathrm{AGFI}=0.95$

Figure 4 describes Religious Belief latent variables model with five (5) indicators: RB1 (giving priority toward local tourism), RB2 (widely accepted), RB3 (religious commanded), RB4 (avoiding haram transaction), and RB5 (doubt in halal product). The measurement model of latent variables Religious Belief (RB) satisfies several main conditions, which is, P-Value $>0.050$ (0.26507), RMSEA $\leq$ 0.08 (0.037), NFI $\geq 0.90$ (0.99), and so forth. All goodness of fit (GoF) measures is fit; therefore, we can conclude that the measurement model of Religious Belief is a fit model. All indicators (RB1, RB2, RB3, RB4, RB5) are identified significant in explaining Religious Belief, as well as its validity and reliability (CR [Construct Reliability] $=0.87 \geq 0.70$ and VE [Variance Extracted] $=0.59 \geq 0.40)$. The finding indicates that giving priority toward local tourism is the highest indicator in explaining the Religious Belief of Muslim on spending to halal travel and tourism consumption, while doubt in halal takes the last priority of the model. 
Figure 4. $1^{\text {st }}$ CFA Measurement Model of Religious Belief T-Value Standardized Solution
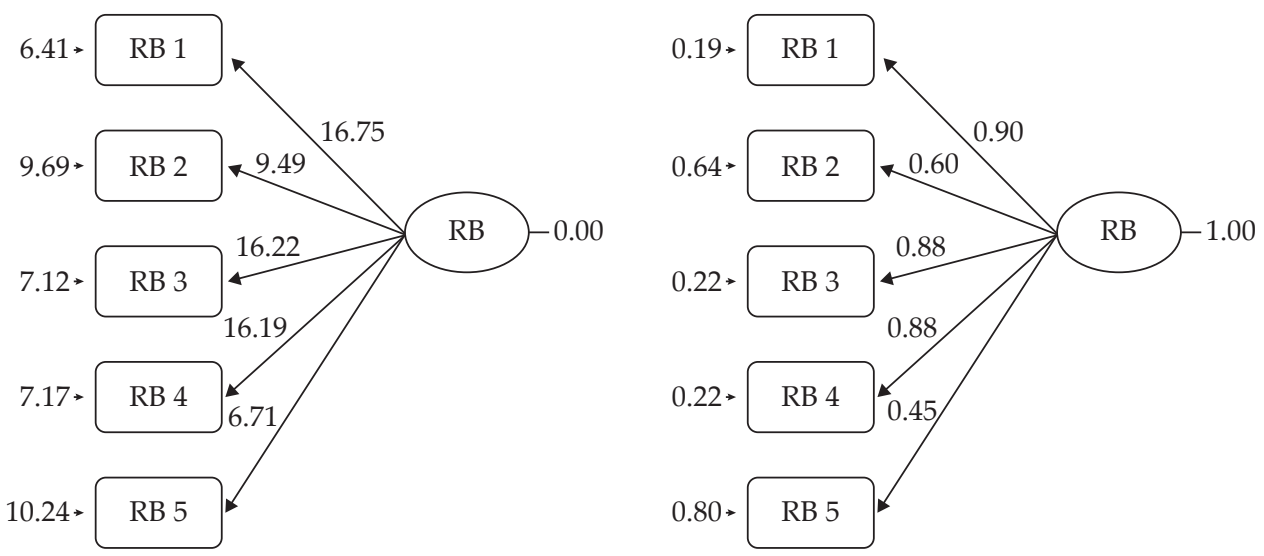

Chi-Square=5.22; $\mathrm{df}=4 ; \mathrm{P}$-Value=0.26507; RMSEA=0.037; NFI=0.99; NNFI=1.00; $\mathrm{CFI}=1.00 ; \mathrm{IFI}=1.00 ; \mathrm{RFI}=0.98 ; \mathrm{GFI}=0.99 ; \mathrm{AGFI}=0.96$

Figure 5 describes Halal Marketing model with five (5) indicators: HM1 (celebrity endorsements), HM2 (halal certification), HM3 (affordable pricing), HM4 (promotion and advertising), and HM5 (unique religious experiences). The measurement model of latent Halal Marketing (HM) satisfies several main conditions, which is, P-Value $>0.050$ (0.29048), RMSEA $\leq 0.08$ (0.033), NFI $\geq 0.90$ (0.97), etc. All goodness of fit (GoF) measures is fit; therefore, we can conclude that the measurement model of Halal Travel and Tourism is a fit model. All indicators (HM2, HM3, HM4, HM5) except HM1 are identified significant in explaining Halal Travel and Tourism, as well as its validity and reliability (CR [Construct Reliability] $=0.68 \geq 0.70$ and VE [Variance Extracted] $=0.40 \geq 0.40)$. Therefore, HM1 will be removed from the model due to the standardized solution value that was below 0.30. The finding indicates that promotion is the highest indicator to explaining the Halal Marketing, while celebrity endorses takes the last priority of the model. 
Figure 5. $1^{\text {st }}$ CFA Measurement Model of Halal Marketing T-Value Standardized Solution
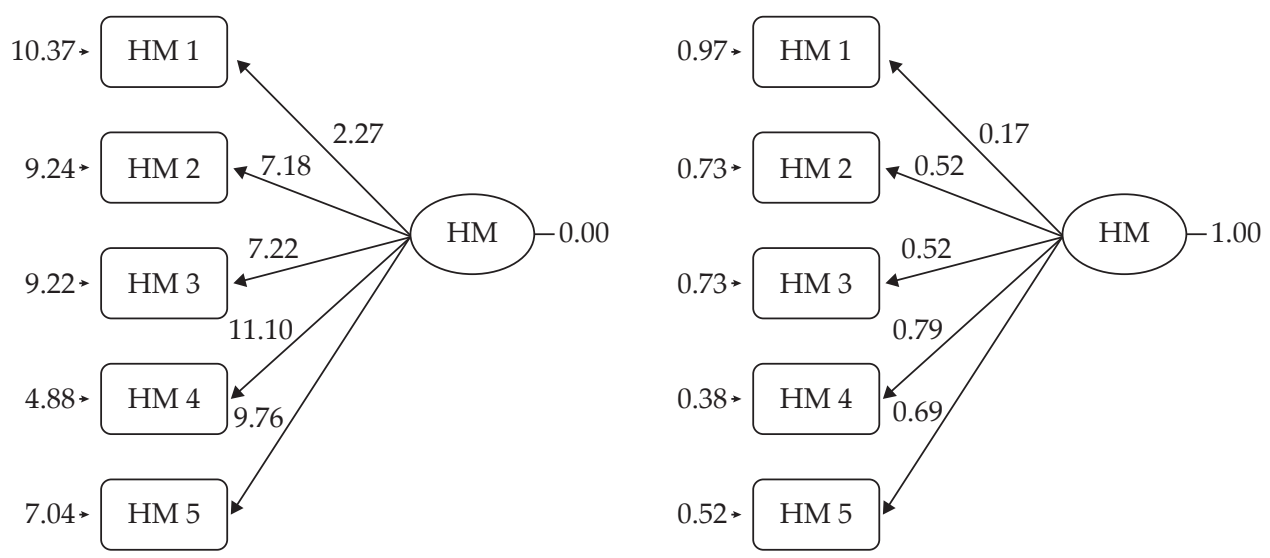

Chi-Square=6.17; $\mathrm{df}=5 ; \mathrm{P}-$ Value $=0.29048 ; \mathrm{RMSEA}=0.033 ; \mathrm{NFI}=0.97$; $\mathrm{NNFI}=0.99 ; \mathrm{CFI}=0.99 ; \mathrm{IFI}=0.99 ; \mathrm{RFI}=0.94 ; \mathrm{GFI}=0.99 ; \mathrm{AGFI}=0.97$

Figure 6 describes Halal Travel and Tourism variables model with five (5) indicators: HT1 (policies and regulations), HT2 (incentives and subsidies), HT3 (long-term road maps), HT4 (priority activity of regional governments), and HT5 (partnerships among stakeholders \& business owners). The measurement model of latent Halal Travel and Tourism (HT) satisfies several main conditions, which is, P-Value $>0.050$ (0.60248), RMSEA $\leq 0.08$ (0.000), NFI $\geq 0.90$ (1.00), and so forth. All goodness of fit $(\mathrm{GoF})$ measures is fit; therefore, we can conclude that the measurement model of Halal Travel and Tourism is a fit model. All indicators (HT1, HT2, HT3, HT4, HT5) are identified significant in explaining Halal Travel and Tourism, as well as its validity and reliability (CR [Construct Reliability] $=0.87$ $\geq 0.70$ and VE [Variance Extracted] $=0.57 \geq 0.40$ ). The finding indicates that longterm road map is the highest indicator to explaining the Halal Travel and Tourism of Muslim on spending to halal travel and tourism consumption, while policy and regulation takes the last priority of the model. 
Figure 6. $1^{\text {st }}$ CFA Measurement Model of Halal Travel and Tourism

T-Value

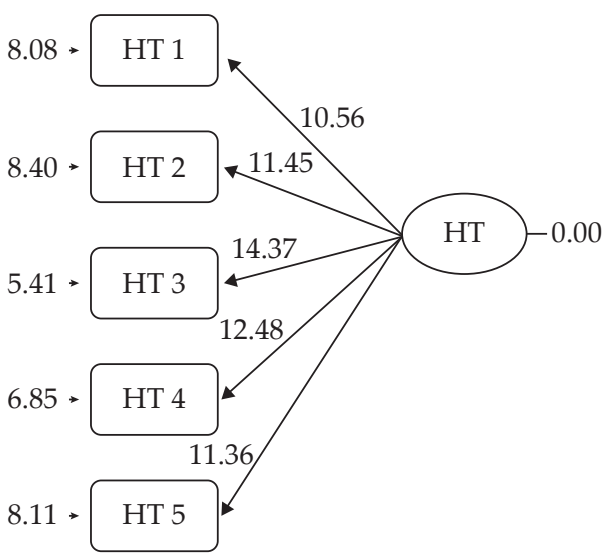

Standardized Solution

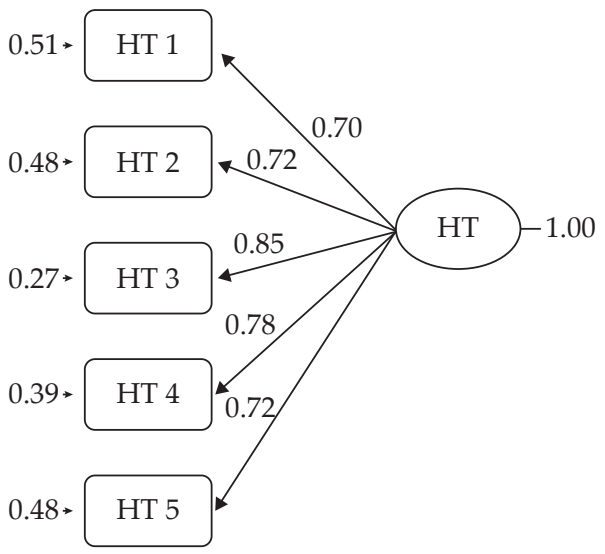

Chi-Square=1.01; df=2; P-Value=0.60248; RMSEA=0.000; NFI=1.00; NNFI=1.01; $\mathrm{CFI}=1.00 ; \mathrm{IFI}=1.00 ; \mathrm{RFI}=0.99 ; \mathrm{GFI}=1.00 ; \mathrm{AGFI}=0.99$

Figure 7 describes Infrastructure variables model with nine (9) indicators: I1 (halal food), I2 (the availability of masjid/mushola), I3 (the availability of water and good sanitation), I4 (service and facility during Ramadhan), I5 (the absence of non halal activities), I6 (private leisure facilities), I7 (employees with good attitude), I8 (Muslim traveler's safety and comfort), I9 (easy access to transportation). The measurement model of latent Infrastructure (I) satisfies several main conditions, which is, RMSEA $\leq 0.08$ (0.067), NFI $\geq 0.90$ (0.99), etc. Almost all goodness of fit $(\mathrm{GoF})$ measures is fit; therefore, we can conclude that the measurement model of Infrastructure is a fit model. All indicators (I1, I2, I3, I4 I7, I8, I9) are identified significant in explaining Infrastructure, as well as its validity and reliability (CR [Construct Reliability] $=0.90 \geq 0.70$ and VE [Variance Extracted] $=0.52 \geq 0.40$ ). The finding indicates that easy access of transportation is the highest indicator to explaining the Halal Travel and Tourism of Muslim on spending to halal travel and tourism consumption, while private leisure facility takes the last priority of the model. 
Figure 7. $1^{\text {st }}$ CFA Measurement Model of Infrastructure

T-Value

Standardized Solution
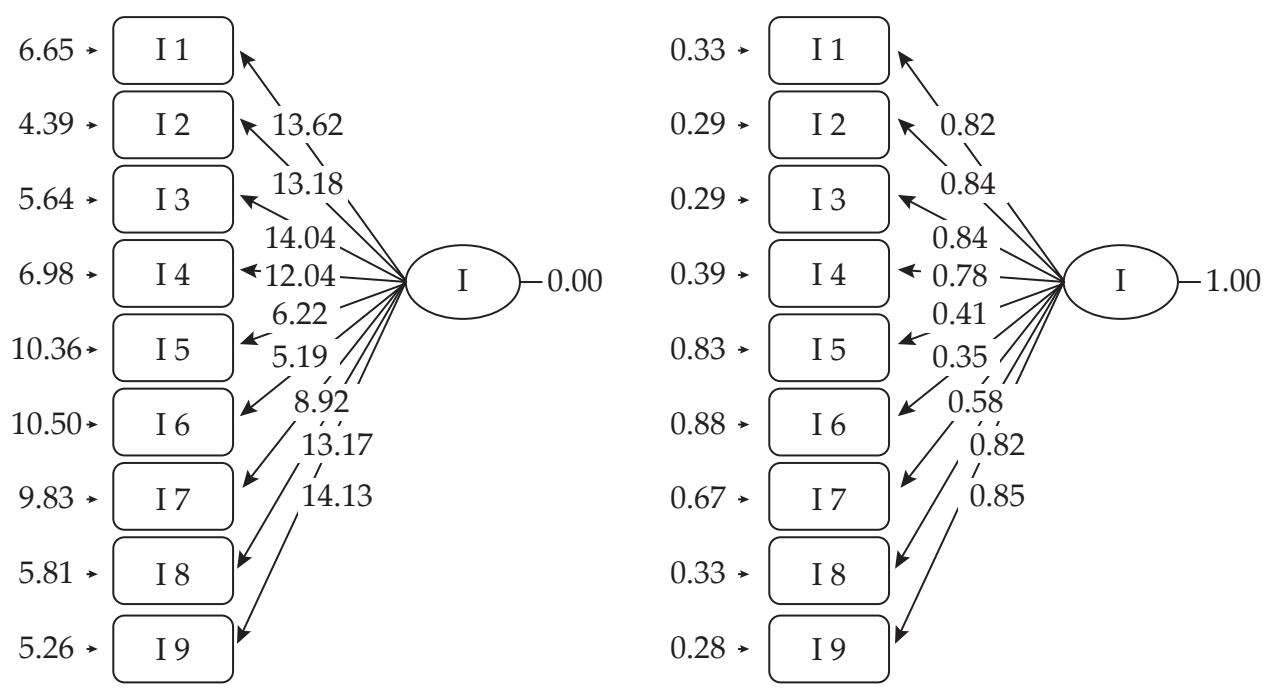

Chi-Square=27.75; df=14; P-Value=0.01535; RMSEA=0.067; NFI=0.99; NNFI=0.98; $\mathrm{CFI}=0.99 ; \mathrm{IFI}=0.99 ; \mathrm{RFI}=0.97 ; \mathrm{GFI}=0.97 ; \mathrm{AGFI}=0.91$

\subsection{Measurement Model of $2^{\text {nd }}$ CFA}

The results of measurement model of 2nd CFA will be discussed in this section thoroughly. Figure 8 describes Purchase Intention latent variables model with five (6) indicators: HA Halal Awareness, PSP Personal Societal Perception, RB Religious Belief, HM Halal Marketing, HT Halal Travel and Tourism, and I Infrastructure. The second CFA model of latent variables Purchase Intention (PI) satisfies five main conditions, which is, RMSEA $\leq 0.08$ (0.079), CFI $>0.9(0.96)$, IFI $>0.9(0.96)$, RFI $>0.9(0.92)$ and NNFI $>0.9(0.96)$, while other part like P-Value < 0.050 (0.000), PNFI $>0.9$ (0.84), and GFI > 0.9 (0.77) indicate marginal fit. According to the Goodness of fit $(\mathrm{GoF})$ measurement, we can conclude that the measurement model of $2^{\text {nd }}$ CFA of purchase intention model is a fit model. All indicators (HA, PSP, RB, HM, HT, I) are identified significant in explaining purchase intention customer toward halal travel and tourism industry in Indonesia, as well as its validity and reliability. The finding indicates that halal marketing is the highest indicators to explaining the purchase intention of Muslim on spending to halal travel and tourism consumption, while personal societal perception takes the last priority of the model. 
Figure 8. $2^{\text {nd }}$ CFA Measurement Model of Purchasing Intention
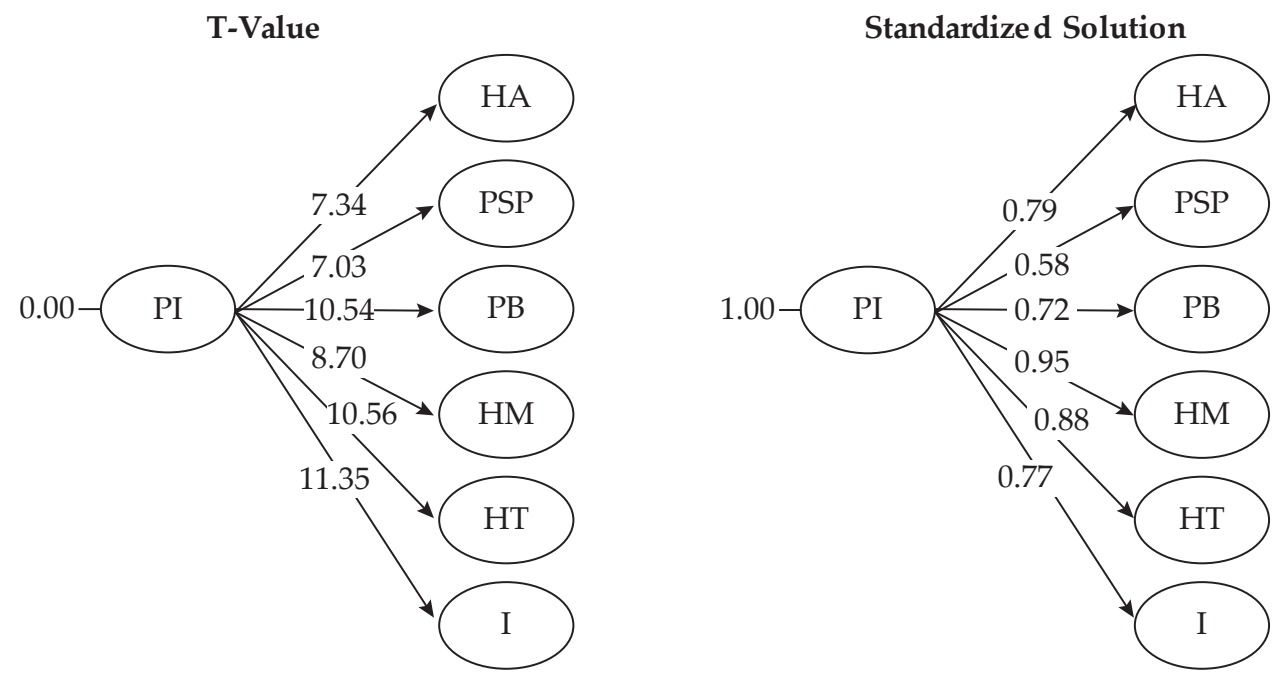

Chi-Square $=986.95, \mathrm{df}=418, \mathrm{p}$-value $=0.0000, \mathrm{RMSEA}=0.079 \mathrm{NFI}=0.93$

$\mathrm{CFI}=0.96, \mathrm{IFI}=0.96, \mathrm{NNFI}=0.96, \mathrm{PNFI}=0.84, \mathrm{RFI}=0.92 \mathrm{GFI}=0.77$

The results provide some important information regarding the measurement factors of Muslim's purchase intention on halal travel and tourism industry in Indonesia. There are six main factors that empirically significant stand for measurement of Muslim's purchase intention, where halal marketing is the top measurement factor, and Halal Travel and Tourism the second place and halal awareness the third. Religious belief and personal societal perception are the last two priorities.

The findings confirm some previous studies (Awan et al., 2015; Winarti, 2017) in that they provide information regarding the importance of halal marketing to improve a Muslim's purchase intention on halal travel and tourism products. Therefore, it is considerably possible that Indonesia will lead to Halal travel and tourism sector in the world. Similarly, Awan et al. (2015) agree that halal awareness will lead to Muslim's purchase intention on halal product and services. Halal infrastructure is considered as the fourth level of importance of the determinants. However, several studies (Gunasekaran \& Ngai, 2003; Jaelani, 2017) addressed the need of supporting infrastructure as well as the government policies. Even though the determinant factor of the urgency of inserting religious aspect toward halal tourism and travel stands at the second last priority, it is slightly vital and greatly supported by previous studies (Ahmed, 2008; Awan et al., 2015; Essoo \& Dibb, 2004; Jaelani, 2017). In particular, the author agrees that spiritual values can affect the lifestyle of customer and their actions on purchasing behavior. 


\section{CONCLUSION AND RECOMMENDATIONS}

\subsection{Conclusion}

The study indicates that halal marketing is the highest indicator to explain the purchase intention of Muslim on spending of the halal travel and tourism consumption. On the other hand, personal societal perception takes the last priority of the model. The availability of halal product and government responsibility on the availability of halal product are the most dominant indicators in explaining the awareness of Muslim on spending halal travel and tourism consumption, with searching detail information being the least dominant indicator of the model. Additionally, positive perception is the highest indicator in explaining the Personal Societal Perception of Muslim on spending halal travel and tourism consumption, while giving priority on halal travel and tourism taking the least dominant indicator of the model. On the other hand, the results indicate that giving priority toward local tourism is the highest indicator to explain the Religious Belief of Muslim on spending to halal travel and tourism consumption. At the same time, doubt in halal takes the last priority of the model. Promotion takes the highest indicator to explaining the Halal Marketing of Muslim on spending to halal travel and tourism consumption, with celebrity endorsements taking the last priority of the model. A long-term road map is the highest indicator in explaining the Halal Travel and Tourism of Muslim on spending to halal travel and tourism consumption. Additionally, policy and regulation takes the last priority of the model. Last, easy access of transportation is the highest indicator in explaining the infrastructure of Halal Travel and Tourism on Muslim's spending to halal travel and tourism consumption, with private leisure facility making the last priority of the model.

\subsection{Recommendations}

The study suggests some policy recommendations for policy makers, practitioners, and academicians. The government should establish an intensive promotion on halal travel and tourism, both on national and international levels. The government is also required to create a long-term road map on halal travel and tourism in Indonesia. Moreover, the government should play a vital role in instilling Muslim awareness on Halal travel and tourism through halal literacy and education.

Practitioners, in particular business owner of halal travel and tourism, should elevate their services on halal travel and tourism in cooperation with regulators by offering easy access for transportation, providing halal food, affording more convenient masjids/musholas, providing clean water and sanitation system, as well as encouraging well-performed employees. Business owners should also strengthen their business on halal travel and tourism by ensuring that their product and services are sharia compliant through registering to halal certification authority.

Further empirical research is required to obtain better understanding and dimension of the Muslim consumer perception on the halal travel and tourism sector by inserting more latent variables and enlarging the surveyed areas. Upgrading analytical tools such as Partial Least Square (PLS) and Structural Equation Modeling (SEM) are recommended to be used in order to find the interrelationship among latent variables respectively. 


\section{REFERENCES}

Ab-Talib, M., Hamid, A., \& Zulfakar, M. (2015). Halal Supply Chain Critical Success Factors: A Literature Review. Journal of Islamic Marketing, 6(1), 44-71.

Ahmed, A. (2008). Marketing of Halal meat in the United Kingdom-Supermarkets versus Local Shops. British Food Journal, 110(7).

Ajzen, I. (1991). The Theory of Planned Behavior. Organizational Behavior and Human Decision Processes, 50(2), 179-211.

Al-Jallad, N. (2008). The Concept of Al-halal and Al-haram in the Arab-Muslim Culture: A Translational and Lexicographical Study. Languange Design: Journal of Theoritical and Experimental Linguistics, 10, 77-86.

Anderson, J. C., \& Gerbing, D. W. (1984). The Effect of Sampling Error on Convergence, Improper Solutions, and Goodness-of-fit indices for Maximum Likelihood Confirmatory Factor Analysis. Psychometrika, 49(2), 155-173.

Ascarya. (2016). Analysis the Determinants of Micro Enterprises Graduation. Paper presented at the 8 th International Management and Accounting Conference (IMAC8).

Awan, H. M., Siddiquei, A. N., \& Haider, Z. (2015). Factors Affecting Halal purchase intention - Evidence from Pakistan's Halal Food Sector. Management Research Review, 38(6), 640-660.

Baumgartner, H., \& Homburg, C. (1996). Applications of Structural Equation Modeling in Marketing and Consumer Research: A Review. International Journal of Research in Marketing, 13(2), 139-161.

Brown, T. A. (2006). Confirmatory Factor Analysis for Applied Research. New York, London: The Guilford Press.

Din, K. (1989). Islam and Tourism: Patterns, Issues, and Options. Annals of Tourism Research, 16(4), 542-563.

Essoo, N., \& Dibb, S. (2004). Religious Influences on Shopping Behavior: An Exploratory Study. Journal of Marketing Management, 20(1), 683-712.

Gunasekaran, A., \& Ngai, E. W. T. (2003). The Successful Management of A Small Logistics Company. International Journal of Physical Distribution $\mathcal{E}$ Logistics Management, 33(9), 825-842.

Hair, J. F., Sarstedt, M., Hopkins, L., \& Kuppelwieser, V. G. (2014). Partial Least Squares Structural Equation Modeling (PLS-SEM) an Emerging Tool in Business Research. European Business Review, 26(2), 106-121.

Jaelani, A. (2017). Halal Tourism Industry in Indonesia: Potential and Prospects. Munich Personal RePEc, 76235.

Johannes, R. (2009). Mission: To Develop a Halal Ecosystem. The New Straits Times Press (M) Berhad.

Liu, Y., Li, I., Yen, S., \& Sher, P. J. (2018). What Makes Muslim Friendly Tourism? An Empirical Study on Destination Image, Tourist Attitude and Travel Intention. Advances in Management \& Applied Economics, 8(5), 27-43.

McStay, D. (2008). An Investigation of Undergraduate Student Self-Employment Intention and The Impact of Entrepreneurship Education and Previous Entrepreneurial Experience. School of Business Bond University, Australia.

Pahim, K. M. B., Jemali, S., \& Mohammad, S. J. A. N. S. (2012). An Empirical Research on Relationship between Demand, People and Awareness towards 
Tarining Needs: A Case Study in Malaysia Halal Logistics Industry. IEEE Business Engineering and Industrial Applications Colloquium (BEIAC), 246-251.

Samori, Z., Salleh, N. Z. M., \& Khalid, M. M. (2016). Current Trends in Halal Tourism: Case on selected Asian Countries. Tourism Management Perspectives, 19, 131-136.

Suligoj, M., \& Marusko, H. (2017). Hotels and Halal-Oriented Products: What Do Hotel Managers in Slovenia Think? Organizacija, 50(4), 314-323.

Tichaawa, T. M., \& Mhlanga, O. (2018). Muslim Tourist Experinces and Return. Acta Universitatis Danubius, 14(4), 42-57.

Tieman, M., Vorst, J. G. A. J. V. D., \& Ghazali, M. C. (2012). Principles in Halal Supply Chain Management. Journal of Islamic Marketing, 3(3), 217-243.

Winarti, O. (2017). Halal tourism in Indonesia: Does it Attract only Muslim Tourists. Jurnal Studi Komunikasi, 1(3), 232-239.

Zakaria, N., \& Abdul-Talib, S. N. (2010). Applying Islamic Market-Oriented Cultural Model to Sensitize Startegies towards Global Customers, Competitors, and Environment. Journal of Islamic Marketing, 1(1), 51-62. 